\title{
高潮災害を対象としたソフト防災に関する考察

\author{
Consideration on Soft- Disaster Prevention Aiming at Storm Surges Disaster
}

\author{
松見吉晴 ${ }^{1} \cdot$ 雁津佳英 ${ }^{2}$ \\ Yoshiharu MATSUMI and Yoshihide GANZU
}

\begin{abstract}
In Sakaiminato district that has received a storm surge disaster, the present study conducted a questionnaire survey for consciousness of residents on the disaster prevention. Additionally, our previous evacuation scenario was extended and improved by including questionnaire entries relative to the conditions of a refuge and an existence of nursing person. By investigating from the statistical approaches regarding the causal relation between the disaster prevention consciousness and the decision making of evacuation, effective policies for the disaster prevention consciousness of residents were considered. The vulnerability in evacuation routes was examined using the improved evacuation simulation model.
\end{abstract}

\section{1. はじめに}

地域防災計画には，従来の防災基盤の整備といったハ ード防災に加え，避難に関する地域住民による自助管理 体制に基づくソフト防災が不可欠と言われている。また 十分なハード防災事業がなされている地域であっても， ハード・ソフトの両面を含めた総合的な地域防災マネジ メント施策を実施することにより, 地域の特性に見合っ た効果的なハード防災整備施策の必要性も明らかにな り，最終的には地域の総合的な防災力の向上が可能にな ると考えられる.

そのための基本ツールとしての避難シミュレーション は，仮想的な避難訓練による行政と住民の意志合意形成 に基づくソフト防災施策の考案に有効な支援ツールであ る．著者らは，住民の防災意識の違いによる避難開始の 意志決定に要する時間変動も考慮したトランザクション 型の避難行動シナリオに基づくネットワーク型の避難シ ミュレーション（松見ら，2008）を開発し，住民の防災 意識の高さによる避難開始時間を変化させた数值実験よ り，避難所要時間の短縮化には住民が高い防災意識を持 つことが不可欠であることを示している.

本研究は, 先の避難行動シナリオをより現実的なもの への改良と, 住民の防㷪意識の向上施策の検討を目的に, 過去に高潮被災を受けた沿岸地区を対象に避難行動に関 する住民の意識, 要介護者や被災経験の有無など世帯の 属性に関するアンケート調査より，住民の防災意識と避 難の意志決定や準備時間等との間の因果関係，並びに住 民の防災意識の向上施策について統計的アプローチより

$\begin{array}{lll}1 \text { 正会員 工博 } & \begin{array}{l}\text { 鳥取大学教授 大学院工学研究科社会基 } \\ \text { 盤工学専攻 } \\ 2 \text { 学生会員 }\end{array} & \begin{array}{l}\text { 鳥取大学大学院工学研究科社会基盤工学 } \\ \text { 専攻 }\end{array}\end{array}$

検討するとともに，改良した避難行動シナリオに基づい て対象地域の避難経路上の脆弱性を評価するものである.

\section{2. 地域住民の防災意識を対象としたアンケート 調查}

(1) アンケートの概要

災害発生時における避難開始時間や住民の意識 - 心理 調査を目的としてアンケート調査を行った研究は数多く 存在している.それらの調査研究は, 避難行動を開始す る要因調査を対象としたもの（例えば，河田ら，1994； 山本ら, 1998 ; 及川, 1999 ; 矢部, 2000 ; 永川ら, 2000), 住民の避難行動開始モデルを対象としたもの（例えば, 早川ら，2002）, 住民の避難行動と心理的要因に着目し たもの（片田ら，2006）に大まかに区分される．特に, 片田らは，津波襲来の危険にさらされた住民の心理と行 動に関する調査を実施し, 住民の避難行動とその背後に ある心理的要因との関連を明らかにしている。本研究で は, このような従来の研究内容を参照して, アンケート 項目を設定することにした.

本研究では，図-1に示す鳥取県境港市渡町・森岡町を 対象に, 日頃の自然災害に対する関心度, 避難勧告時の 避難意志の有無, 避難決意の条件と所要時間, 避難準備 時間等についてアンケート設問を設けるとともに, 高潮 被災の経験, 住居の海からの距離, 要介護者の有無等の 世帯の属性についても調査した。渡町は中海に面してお り，過去に高潮による浸水災害（最近では，2004年 8 月 20 日）の経験がある地域である。アンケートの回収状況 は, 全 1508 世带へ配布し, 回収数 574 の内, 有効回答数 が556で回収率が36.9\%であった。

アンケートの内容は大きく4つの設問を設け，主に多 肢選択法で回答を求めた。まず，1番目の設問は自然災 害に対する日頃の意識や行動について, 表-1に示す 10 項 


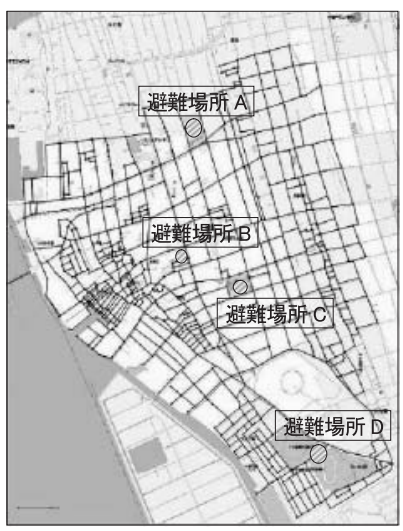

図-1 対象地域と道路ネットワーク

表-1＼cjkstart防災意識に関する設問内容

\begin{tabular}{c|l}
\hline 項目 & \multicolumn{1}{|c}{ 内 容 } \\
\hline (1) & 防災マップの所持 \\
\hline (2) & 非常時持出物品の用意 \\
\hline (3) & 避難場所と避難経路の把握 \\
\hline (4) & 防災訓練や防災活動に参加 \\
\hline (5) & 災害時の保険加入 \\
\hline (6) & テレビやラジオから地域の災害や防災情報を収集 \\
\hline (7) & インターネットから地域の災害や防災情報を収集 \\
\hline (8) & 日本に上陸しそうな台風に注意を払う \\
\hline (9) & 発令された注意報や警報に注意を払う \\
\hline (10) & 高潮発生時の自宅や周辺の危険性を想定 \\
\hline
\end{tabular}

目から選択するものである．2番目の設問では，高潮警 報発令時もしくは避難勧告時に避難するか否かに関する 項目と，避難を決意するための条件として，自宅周辺の 被害状況，家族の居場所の把握状況，近所の人の行動に 関する項目により構成されている. 3 番目の設問では, 避難準備に要する時間，避難場所と経路設定の有無，移 動手段についてである４番目の設問では高潮の被災経 験の有無, 住居の海からの距離，要介護者の有無などの 世帯の属性に関するものである。

\section{(2) アンケート結果}

図-2 は，表-1に示す 10 項目の防災に係わる普段の意識 や行動に関する複数回答結果を示したものである。一般 的な結果として，「8日本に上陸しそうな台風に注意を 払う」が最も多く，次に「(9)発令された注意報や警報に 注意を払う」が多いことが分かる。一方，少数回答とし て，「(1)防災マップの所持」，「(2)非常時持出用品の用意」, 「7)インターネットから地域の自然災害や防災情報を収 集」があげられている.

図-3は, 高潮警報発令時, あるいは避難勧告時におけ る行動に関する回答結果を示したものである。「1直ち

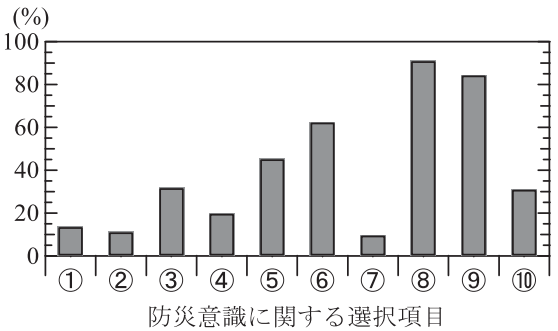

図-2＼cjkstart防災に関する普段の意識や行動

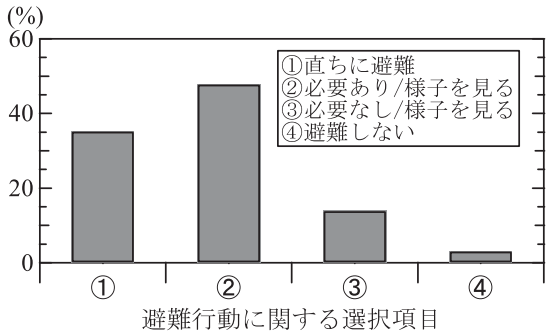

図-3 高潮警報, 避難勧告時の住民の行動選択

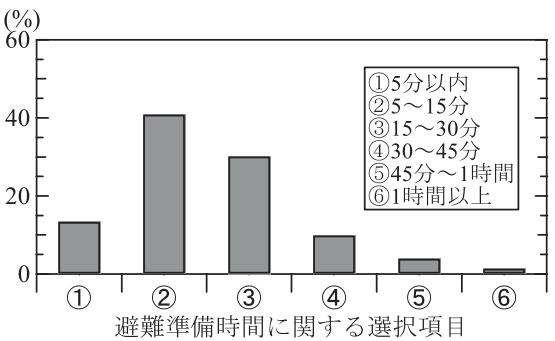

図-4 避難準備に要する時間

に避難」の回答率が $35 \%$ 程度ある。また，「(2避難する 必要があるが，しばらく様子を見る」世帯の割合が「(3) 避難する必要はないが，しばらく様子を見る」と比較し て高い結果を示している。このことから，地域住民の多 くは，高潮警報時あるいは避難勧告時において自らが置 かれている状態に危機感を感じてはいるものの，決定的 に避難をしなければならない状態には至っていないと判 断しているものと推察される.

図-4は，避難準備に要する時間に関する回答結果をま とめたものである.この地区の傾向として，30分以内に 準備を終える世带が 8 割を超え，1時間以内にはほぼ全て の世帯が準備を完了させることが分かる.

要介護者の有無に関する回答では，約 10\%の世帯に要 介護者がいることわかった。なお，その際の聞き取り調 查で，境港市は図上訓練などを通して災害時要援護者が いる世帯を把握しているが，災害発生時に地区による協 力体制ができていないとの意見もあった.

\section{3. 住民の防災意識向上策に関する考察}

ここでは，アンケート調査より住民の防災意識向上策 
に関する検討を目的に, 住民の防災意識と避難の意志決 定や準備時間等との間の因果関係や，住民の防災意識向 上への施策について統計的手法に基づいて同定化する.

（1）住民の防災意識と避難開始タイミングの関係

本研究では, 防災に対する住民の意識の違いが避難開 始タイミングに影響を及ぼすと考えている。この考え方 の検証のため，アンケートより得られた表-1に示す防災 意識に関する該当項目数と, 避難決意時間および避難準 備時間の間に㧍ける因果関係について, 共分散構造分析 （例えば，豊田，2007）を用いて分析した結果を図-5に 示す。この共分散構造解析は, 因子分析と多重回帰分析 （パス解析）を拡張したようなものである.

まず, 図-5に示す3項目の関連分析モデルの適用性に ついて, 共分散構造解析に扔ける適合度指標の1つであ る平均二乗䛊差平方根（RMSEA）はゼロであった。一 般的にRMSEAが 0.05 未満の場合, モデルの当てはまり がよいと言われていることから，図-5のパス分析モデル の妥当性が確認できた。 また，この図に示す該当項目数 と避難決意時間および避難準備時間へのパス值と, それ ぞれの有為確率の関係を調べた結果, 該当項目数と避難 決意時間の間には高度に有為な推定值であることがわか った。一方, 該当項目数と避難準備時間との関係は有為 な結果とは言えなかった。

以上の検定結果を踏まえて図-5より, 該当項目数から 避難決意時間へのパス係数が 0.14 と高度に有意であるこ とから, 該当項目数の増加が避難決意時間の短縮化に効 果的であることが確認できる. また, 該当項目数から避 難準備時間へのパス係数は 0.03 であり, 避難決意時間へ のパス係数と比べると, 影響度が $1 / 10$ 以下である。この ことから，地域住民に扔いて表-1に示すような日頃の防 災に備える意識や行動に関する項目数が多くなれば, 避 難意志決定の時間の短縮化がはかられ, その結果, 地域 住民による避難に関するスムーズな自助管理の確立につ ながるものと言えよう。

\section{（2）避難決意時間を短縮する対策}

住民の防災意識の向上化策を検討するため, 表-1に示 す各世帯に扔ける防災意識に関する該当項目数と避難意 向の調査結果（直ちに避難する，しないの区分）に関す るクラスター分析結果を図-6に示す。この図より，住民 が避難勧告を受けて直ちに避難を決意するためには, 防 災意識に関する該当項目数が7 項目以上必要であること がわかる，そこで，図-2において多くの世帯が既に該当 している項目としては，「8日本に上陸しそうな台風に 注意を払う」世帯が $91.0 \%$ ，「(9)発令された注意報や警 報に注意を払う」世帯が $84.4 \%$ ，「6 (6)テレ゙やラジオか ら地域の災害や防災情報を収集」世帯が $62.4 \%$ ，「(5)災 害時の保険加入」世帯が $45.3 \%$ となっている. 反対に,

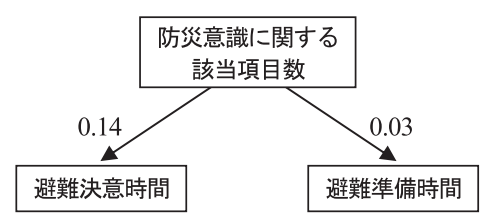

図-5 防災意識に関する回答項目数と避難行動開始夕イミン グのパス図

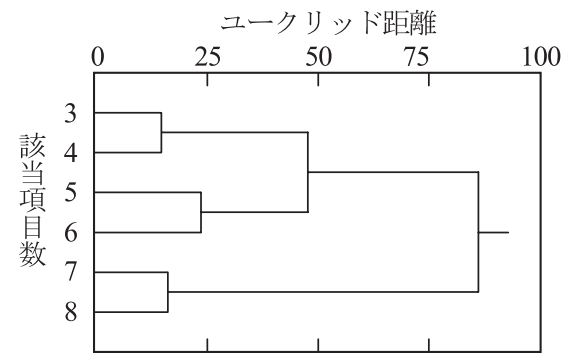

図-6 防災意識に関する該当項目数と避難意向に関するクラ スター分析結果

該当世帯数が少ない項目は,「(1)防災マップの所持」世 帯が $13.7 \%$,「(2)非常時持出物品の用意」世帯が $11.2 \%$, 「7 インターネットから地域の災害や防災情報を収集」 世帯が $9.7 \%$ とっている。 そこで, 例えば, 行政側が 防災マップの普及, 非常時持出物品に関する広報活動, リアルタイムでの情報提供の工夫などをはかる施策をと ることにより，7項目以上に該当する世帯数が増える. その結果として, より多くの住民のすばやい避難行動が 期待できよう。

（3）避難決意時間短縮のための対策の有効性の評価

ここでは, 避難決意時間の短縮化対策の有効性を検討 するため, 住民の防災マップ所持, 防災訓練参加, 非常 時持出物品用意が, 共分散構造解析における潜在変数と しての防災意識（具体的に調査不可能なもの）にどの程 度の影響を及ぼしているかについて, 被災経験や要介護 者の影響度との比較も踏まえて検討する。

図-7は, 防災意識の向上が避難決意時間や準備時間の 短縮化, 避難経路の事前設定に及ほす影響について共分 散構造分析した結果を示したものである。この図より, 防災意識をとりまく調査可能な各種要因と防災意識の因 果関係は, 防災マップ所持㧍よび避難訓練参加から防災 意識へのパス係数が高い值を示すとともに, 非標準化推 定值でも $1 \%$ 水準で有意が認められおり, 住民の防災意 識の向上にはこれら2つが重要な要因となることが確認 できる．また，住民の防災意識向上の結果，避難場所・ 避難経路の事前設定へのパス值が高くなることもわかる.

\section{4. 避難所要時間と避難経路上の脆弱性評価}

（1）避難シミュレーションの改良

松見・蘆田の避難行動シナリオ（2008）において, 危 


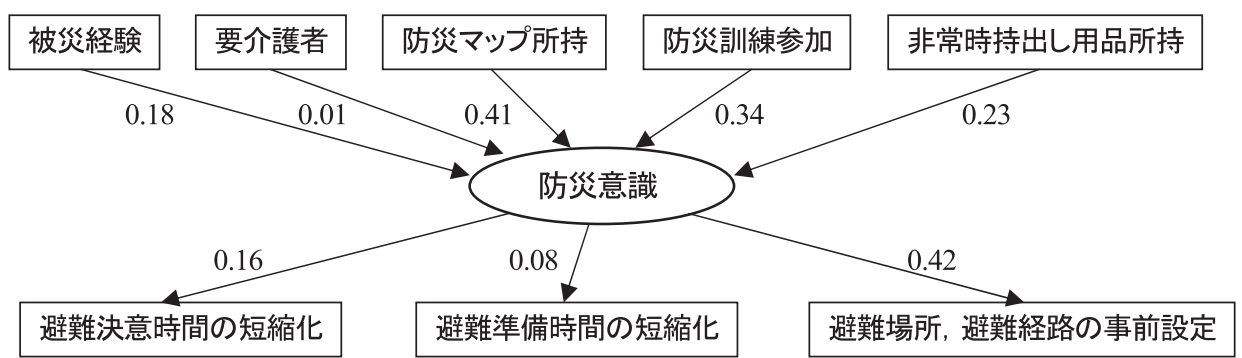

図-7 防災意識を介した因果関係分析

機認識の度合いには個人の防災意識の高さが関与すると 考え，住民の防災意識の違いによる避難開始の意志決定 に要する時間変動を考慮したものであった，具体的には， 防災意識の高いグループと低いグループに分け，各グル 一プの避難開始時間を便宜的に以下に示す平均值 $\mu$ と標 準偏差 $\sigma$ をつ正規分布に従う乱数で与えている．防災 意識の高いグループの場合は $\mu=3$ 分， $\sigma=1$ 分，低いグル ープの場合は $\mu=20$ 分， $\sigma=6$ 分 40 秒と設定していた.

図-7に示したように避難決意時間，避難準備時間につ いては共分散構造分析において，いずれの観測変数や潜 在変数からも強い影響が認められなかったことから，本 研究では防災意識の違いで区別せず，アンケート結果の 避難準備時間に関する統計分析より，平均準備時間は $\mu$ $=17.99$ 分, 標準偏差は $\sigma=13.78$ 分と設定した。なお，確 率分布を正規分布と仮定し，標準偏差を平均值の $1 / 3$ と している，その結果，標準偏差は5.997分を得ている.

また図-8は，アンケート結果より避難を決意する条件 をまとめたものである。「避難する必要があるが，しば らく様子を見る」世帯，「避難する必要はないが，しば らく様子を見る」世帯も，「(7)町内会・近所の人からの 避難の呼び掛け」条件を選択する世帯が多いことがわか る。すなわち，住民の避難の意思決定に対して，呼び掛 け行為が最も効果的であることを示している。 そこで, 避難行動シナリオの改良には, 隣住民の呼び掛けを避難 行動アルゴリズムに導入した。数值計算では，直ちに避 難する世帯と自宅で待機する世帯の割合をアンケート結 果により 1:2とした.

\section{（2）指定避難場所までの所要時間}

本研究では, 避難場所までの避難所要時間の算定に当 たって，世带毎の避難開始時間に関して先の分析より得 られた確率特性に基づいてランダムに与えるとともに， 避難の呼び掛けを待つか待たないかの属性に関して計 500 種類のシミュレーションを実行した。表-2は，図-1 に示す対象地区の 4 ケ所の避難場所までの避難所要時間 について最大，最小及び平均時間を示したものである。 な押，避難シミュレーションに打いて各世帯が避難に向 かう場所は，世帯の初期位置から各避難場所までの危険

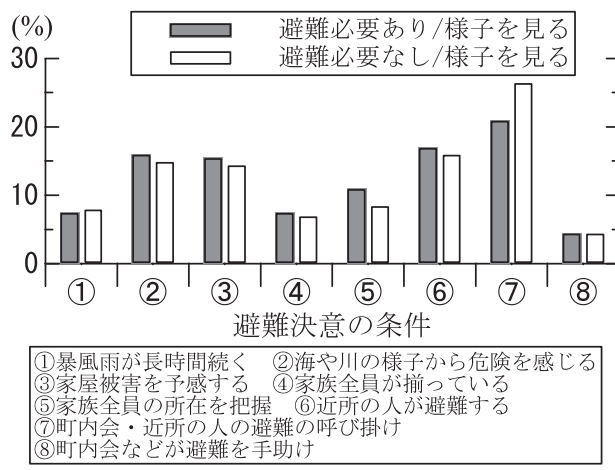

図-8 避難を決意する条件

表-2 各避難場所までの避難所要時間

\begin{tabular}{c|c|c|c}
\hline & 最大所要時間 & 最小所要時間 & 平均所要時間 \\
\hline 避難場所 $\mathrm{A}$ & 92 分 27 秒 & 68 分42秒 & 77分30秒 \\
\hline 避難場所 $\mathrm{B}$ & 79 分46秒 & 57 分37秒 & 65 分51秒 \\
\hline 避難場所 $\mathrm{C}$ & 82 分07秒 & 58 分 08 秒 & 67 分06秒 \\
\hline 避難場所D & 77 分09秒 & 47 分12秒 & 61 分11秒 \\
\hline
\end{tabular}

度ポテンシャル（松見ら，2008）と避難場所の収容世带 数によって決定した。すなわち，危険度ポテンシャルが 小さくなる避難場所にまず避難することを想定し，次い で収容世帯数より溢れた避難場所へ計算された世帯の一 部を収容世帯数に余裕のある避難場所へ避難するように 避難行動アルゴリズムを設定した。表-2より，最も避難 に時間がかかるのは避難場所 $\mathrm{A}$ に避難する世帯で，最大 で1時間半近くかかる可能性があるが，4箇所の避難場所 までの平均所要時間の差は 10 数分程度でもある.

\section{（3）避難経路上の脆弱性評価}

ここでは，地域住民に対する防災意識の向上策が進み， 避難勧告と同時に地域の全世帯が避難をはじめることを 想定し，この地域の避難経路上の脆弱性について検討す る。図-9（A）は，避難最大所要時間を便宜的に 2100 秒 （35分）に設定し，対象地域内のすべてのノードに対応 する世帯分だけをランダムに 200 種類配置させ，避難勧 告後に直ちに避難を開始すると仮定した時の各避難場所 における避難所要時間を示したものである。この結果よ 


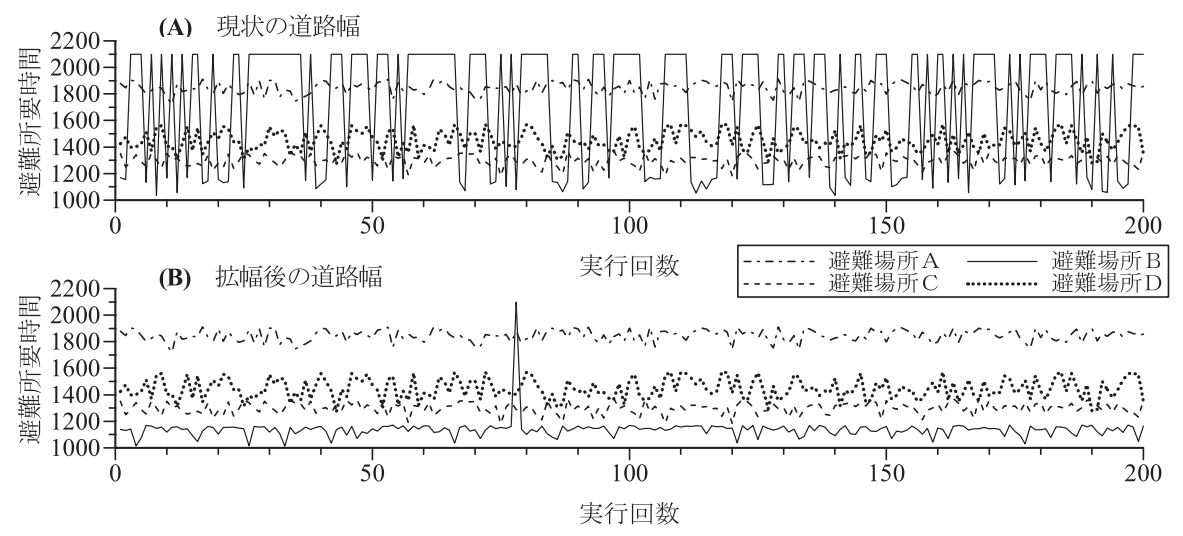

図-9 各避難場所の避難時間（2100秒以内）

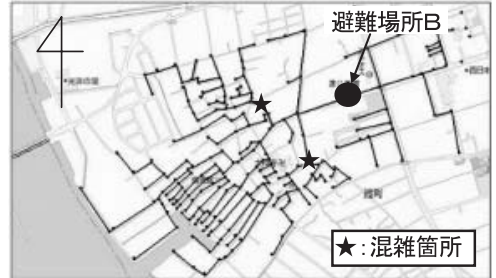

図-10 避難場所 B 周辺の通行不能が生じた場所

り, 避難場所 Bにおいて頻繁に避難時間が 2100 秒を越え る場合がある。そこで,このときのシミュレーションを 視覚的に捉えた結果, 図-10において避難場所Bの西側と 南西側にれ印で明記している2箇所のノードで，世帯の 集まりに伴う混雑により全く進行できない状況が発生し ていることがわかった。この2箇所のノードの先の道幅 が $1.5 \mathrm{~m}, 1.2 \mathrm{~m}$ と大変狭い道路であり, そのため多くの世 帯が集中し通行が難しくなったと考えられる. 対象地域 において, この2箇所が避難経路として脆弱性が高いこ とになる。そこで, 混雑が発生した道幅を $1 \mathrm{~m}$ 拡幅して 再計算した結果を示す図-9（B）より明らかなように,

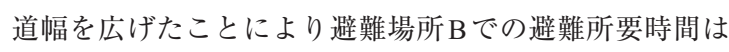
短くなるとともに，時間の遅延もほとんどなくなった.

\section{5. まとめ}

本研究では, 先の避難行動シナリオをより現実なもの への拡張, 並びに住民の防災意識の向上施策の検討を目 的に, 過去に高潮被災を受けた鳥取県境港の沿岸地区を 対象に防災や，高潮警報発令時あるいは避難勧告時にお ける避難行動に関するアンケート調査より，住民の防災 意識と避難の意志決定との因果関係，並びに住民の防災 意識の向上策について検討した. 次いで, アンケート調 査に基づいて改良した, 避難行動シナリオに基づき対象 地域の避難場所までの所要時間, 避難経路上の脆弱性を 評価した。以下に得られた知見を示す。
住民の防災意識に関する普段の行動項目数と避難決意 時間の短縮化との間の強い因果関係が確認できたが, 避 難準備時間の短縮化に対して防災の意識の影響があまり ないことがわかった．住民の防災意識を高める施策とし て, 防災マップの普及, 非常時持出用品に関する広報活 動やリアルタイムでの情報提供等が効果的なものであ る.また, 避難所要時間に関しては, 隣住民による避難 呼び掛けを導入した計算結果より最大で 1 時間半近くか かる世帯の存在がわかった，さらに，住民の防災意識の 向上がはかられて, 地域の全世帯が同時に避難開始する ことを想定した場合の避難経路上の脆弱性評価より, 道 路幅の搪幅が必要となる避難経路が明らかになった。

最後に, 本研究は持続的過疎社会形成研究プロジェク 卜 (研究代表者: 鳥取大学大学院 細井由彦教授) の補助 によることを記して謝意を表する。

\section{参 考 文 献}

及川 康・片田敏孝（1999）：河川洪水時の避難行動における 洪水経験の影響構造に関する研究, 自然災害科学, Vol.18, No.1, pp. 103-118.

片田敏孝・桑沢敏行 · 金井昌信 - 巟玉 真 (2004) : 津波防災 の実態にみる安全・安心に関わる社会技術に関する基礎 的研究, 社会技術研究論文集, Vol.2, pp. 191-198.

河田恵昭・長谷川茂樹（1994）：地震津波警報の伝達とマニュ アルについて, 海岸工学論文集, 第41巻, pp.1186-1190.

永川賢治・今村文彦（2000）：津波防災対策の現状把握と防災 力評価法の提案, 津波工学研究報告, 第 17号, pp.79-94.

早川哲史・今村文彦 (2002)：津波発生時に扔ける避難行動開 始モデルの提案とその適用, 自然災害科学, Vol.20, No.2, pp.51-66.

松見吉晴・蘆田哲也（2008）：沿岸過疎地域の浸水災害を対象 とした避難シミュレーション開発, 海岸工学論文集, 第 55 巻, pp. 1376-1380.

矢部浩規 (2000)：氾濫特性に応じた避難情報提供に関する研 究, 自然災害科学, Vol.19, No.1, pp. 111-120.

山本尚明・村上仁士 ·上月康則・後藤田忠久（1998）：四国に おける津波被災地住民の意識構造分析に基づく津波防災 のあり方について, 海岸工学論文集, 第45巻, pp. 381-385. 